\title{
ETHICAL DILEMMAS AND PRINCIPLES IN ORGAN TRANSPLANTATION IN CHINA
}

\author{
Zhen Zhang $1^{1}$, Zheng Zang $2^{2 *}$
}

\begin{abstract}
In medical clinical practice, organ transplantation is mainly applied to patients with end-stage organ lesions and organ failure. However, with the development of organ transplantation, many ethical issues and controversies have arisen. From the perspective of bioethics, the article compares the relevant ethical and legal regulations of organ transplantation in various countries. Due to the complexity of the real situation, many ethical dilemmas arise in organ transplantation in China. The article analyzes and researches three aspects of organ donation, distribution, and trading, and finds that there are various ethical problems in these three aspects of organ transplantation in China, such as whether the principle of presumed consent is ethical, whether brain death is legalized, the selection and determination of transplant patients, and whether human organ trading is legalized, etc. With the help of the four principles of bioethics and the current development of organ transplantation in China, the article proposes that organ transplantation in China should follow four ethical principles: the principle of respect for life, the principle of do no harm/benefit, the principle of respect for autonomy, and the principle of justice, in order to provide a defense for the legitimacy of organ transplantation.
\end{abstract}

Keywords: organ transplantation; ethical dilemmas; ethical principles; brain death; human organ trade

\section{Dilemas y principios éticos en el trasplante de órganos en China}

En la práctica clínica médica, el trasplante de órganos se aplica principalmente a los pacientes con lesiones orgánicas en fase terminal y con insuficiencia orgánica. Sin embargo, con el desarrollo del trasplante de órganos han surgido muchas cuestiones éticas y controversias. Desde la perspectiva de la bioética, el artículo compara las normas éticas y jurídicas pertinentes del trasplante de órganos en varios países. Debido a la complejidad de la situación real, surgen muchos dilemas éticos en el trasplante de órganos en China. El artículo analiza e investiga tres aspectos de la donación, la distribución y el comercio de órganos, y constata que hay varios problemas éticos en estos tres aspectos del trasplante de órganos en China, como si el principio del consentimiento presunto es ético, si la muerte cerebral está legalizada, la selección y determinación de los pacientes de trasplante y si el comercio de órganos humanos está legalizado, etc. Con la ayuda de los cuatro principios de la bioética y el desarrollo actual del trasplante de órganos en China, el artículo propone que el trasplante de órganos en China debe seguir cuatro principios éticos: respeto a la vida, no hacer daño/beneficio, respeto a la autonomía y justicia, con el fin de proporcionar una defensa de la legitimidad del trasplante de órganos.

Palabras clave: trasplante de órganos, dilemas éticos, principios éticos, muerte cerebral, comercio de órganos humanos

\section{Dilemas e Princípios Éticos no Transplante de Órgáos na China}

Resumo: Na prática clínica médica, o transplante de órgãos é principalmente destinado a pacientes em estágio final de lesōes e falência dos órgãos. Entretanto, com o desenvolvimento do transplante de órgáos, surgiram muitas questôes e controvérsias éticas. O artigo compara, desde uma perspectiva bioética, as regulaçóes éticas e legais relevantes sobre transplantes de órgãos em vários países. Devido à complexidade da situação real, muitos dilemas éticos surgiram no transplante de órgãos na China. $\mathrm{O}$ artigo analisa e investiga aspectos de doação, distribuição e comercialização de órgãos, e encontra que há vários problemas éticos nestes três aspectos do transplante de órgãos na China, tais como se o princípio do consentimento presumido é ético, se morte cerebral é legalizada, a seleção e determinação de pacientes que irão receber transplante, se a comercialização de órgãos humanos é legalizada, etc. $\mathrm{O}$ artigo propóe, com a ajuda de quatro princípios da bioética e o desenvolvimento atual de transplante de órgãos na China, que o transplante de órgãos na China deve seguir quatro princípios éticos: respeito à vida, beneficiar/ não causar dano, respeito pela autonomia e justiça, de forma a possibilitar a defesa da legitimidade do transplante de órgãos.

Palavras chave: transplante de órgãos, dilemas éticos, princípios éticos, morte cerebral, comércio de órgãos humanos

\footnotetext{
${ }^{1}$ Faculty of Economics and Management, Wuhan Railway Vocational College of Technology, Wuhan 430079, China. ORCID: https:// orcid.org/0000-0001-9539-1144

${ }^{2}$ School of Marxism, Soochow University, Suzhou 215006, China; zzhso@qq.com. ORCID: https://orcid.org/0000-0001-5662-0741

Correspondence: zzhso@qq.com.
} 


\section{Introduction}

In 1954, the first kidney transplantation between identical twins in the world was successfully performed in a hospital in Boston, which opened up a new era of organ transplantation. In the 1960s, organ transplantation began to develop in China(1). In more than half a century, on the one hand, autologous liver transplantation, ischemia-free liver transplantation and other organ transplantation technologies have achieved international leadership. On the other hand, the source of transplanted organs has also successfully transformed from using of organs of death penalty criminals to the voluntary donation from citizens. However, organ transplantation in China has achieved continuous breakthroughs in medical technology, but it has been hindered frequently in the moral level(2). It is obvious that there are many ethical issues and controversies in the field of organ transplantation in China, which invariably limit the development of organ transplantation and the expansion of its application. Therefore, it is necessary to analyze and study these ethical issues.

At present, academic research focuses on the ethical issues involved in the organ transplantation process from the perspective of the operation and donation of organs. Organs are often understood as a resource(3). However, the severe shortage of organs has resulted in organs becoming not only a resource, but a commodity(4).

With regard to the rights and interests of donors and recipients, both donors and recipients suffer from high psychological burden, lack of selfidentity, the dangers of xenotransplantation, and ethical problems of social discrimination(5). At the same time, it is difficult to guarantee the informed consent of both parties due to factors such as the literacy level of the donor and the recipient and the ethical level of the medical staff(6).

With regard to the source and use of transplanted organs, the unfairness of the organ allocation process and the lack of standards for doctors' authority have led to a series of problems in organ transplantation, such as the lack of sources of organs available for transplantation, difficulties in protecting the rights of donors, difficulties in realizing the interests of recipients, and abuse of authority by doctors (7). While living organ donation is mainly a question of whether organs can be removed from living bodies, cadaveric organ donation cannot be carried out due to the traditional view of life and death, traditional ethics, and the criteria for judging death(8). The use of organs from executed prisoners for organ transplants faces even more serious ethical issues(9).

With regard to the legalization of human organ trade, many scholars deny the legitimacy of human organ trade, deny the possibility of human organs becoming marketable commodities from a moralistic perspective, and argue that organ trade exploits the health and life chances of the poor and exacerbates social inequality from a consequentialist perspective(10). From the perspective of body ethics, some scholars believe that the legalization of human organs does not have the fundamental property of a commodity, and that the legalization of human organ trade reduces human organs to a commodity, undermines human dignity, deprives donors of their health and the right to dispose of their bodies, and increases social injustice(11).

In general, the conclusions reached by scholars from different research perspectives are relatively scattered and general, mainly focusing on unfair organ allocation, commercialization of human organs, imperfect protection of donor-recipient rights and interests, and lack of transplant organs. Meanwhile, some scholars have also begun to explore the ethical issues resulting from the use of communication media such as the Internet to openly recruit organ donors from the public and to propose solutions(12).

\section{Ethics and legal norms of organ transplanta- tion across countries}

As the name implies, organ transplantation is a medical technique that surgically removes a normal, healthy organ or part of it from an individual's body and transplants it into itself or another individual to replace the latter's damaged, diseased, necrotic, or malfunctioning organ, thereby restoring the patient's health(13). These human organs for transplantation are generally derived from cadaveric organ donations and living organ 
donations. The process of organ transplantation involves two subjects, the donor, the individual who provides the transplanted organ, and the recipient, the individual who receives the transplanted organ. Therefore, from the perspective of the donor-recipient, organ transplantation can be divided into autologous organ transplantation, allogeneic organ transplantation, and xenogeneic organ transplantation(14). Usually, when we talk about organ transplantation, we generally mean that organ transplantation occurs between different individuals of the same species, i.e., homologous allogeneic organ transplantation(15). Therefore, this article is a study of allogeneic organ transplantation.

In clinical practice, as a highly effective and direct medical tool, organ transplantation is primarily used to treat and restore patients with end-stage organ disease and organ failure who are at risk of death due to the ineffectiveness of other treatments(16). It is obvious that organ transplantation has an undeniable role and value in treating organ diseases, saving patients' lives, improving the quality of survival and extending human life.

Unlike developed countries, China only started to develop organ transplantation in the 1960s and 1970s. By the end of 1980s, organ transplantation in China had already formed a certain scale. Today, China has become the second largest organ transplantation country after the United States.

Due to the unique significance and medical value of organ transplantation, Western countries such as the United States, Germany, France, and Turkey have introduced several organ transplantation-related laws and regulations to determine the legality and legitimacy of organ transplantation in the form of legislation in order to meet the development needs of organ transplantation. For example, the laws of the United States, Germany, and Turkey respect the wishes of individual citizens and implement the principle of voluntary organ donation, emphasizing that the donor's wishes are primary and take precedence over the wishes of relatives(17). In Japan, South Korea and other countries, although the law stipulates that the removal of organs after the death of citizens needs the dual consent of donors and their families, it still reflects that citizens have a certain degree of autonomy(18). In France, Spain, and Singapore, the law promotes the principle of "presumed consent" for donations $(19,20)$. This means that unless a citizen has personally expressed an explicit objection to organ donation before death, the government presumes that they have consented to donate after death and allows doctors to remove the required organs. Obviously, this principle of donation is mandatory. In terms of organ transplant organization, specialized organ transplant agencies affiliated with the state, such as the Organ Acquisition and Transplantation Network and the French Institute of Biomedical Research, have been established under the laws of the United States and France(21). In terms of organ trading, most countries in the world have passed laws explicitly prohibiting the sale of human organs, except for a very few countries such as Iran(22). Even though the trade in human organs provides more sources of organs for transplantation, there is still no place in law for organ trading. It is worth noting that some countries and regions have laws that explicitly reward organ donors and allow financial compensation to organ donors to encourage citizen organ donation. Iran is currently the only country in the world that allows paid kidney donation(23). France, Canada, Singapore, Wisconsin in the United States have implemented various incentives such as reimbursement of transportation and accommodation costs, medical benefits, and tax and medical fee waivers(24). In addition to this, organ donors from Israel, Singapore, and South Korea can enjoy priority when it comes to organ allocation(25).

In contrast, the rule of law for organ transplantation in China started late, and the relevant legal norms are not yet perfect(26). China's first special law on organ transplantation, the Regulations on Human Organ Transplantation, was promulgated in 2007. The regulations state the scope of donor recipients, the principle of voluntary and free organ donation, the prohibition of commercial trade in human organs, the strict limitation of live organ transplantation, and the provision of an admission system for medical institutions. In 2011, the Amendment to the Criminal Law of the People's Republic of China (VIII) added the 
crime of involuntary organ harvesting and selling human organs. And in 2013, the Regulations on the Administration of the Acquisition and Distribution of Human Donor Organs (for Trial Implementation) clearly defined the acquisition of donor organs, the distribution of donor organs, and the supervision and management(27). In 2015, China's organ sources achieved a fundamental transition from the use of organs from death row inmates to voluntary donations from citizens. Many local regulations and policies have also been implemented. Organ transplantation in China has gradually formed a legal, standardized and internationalized management model with Chinese characteristics.

Obviously, from the legal provisions of organ transplantation, Western countries focus on the will of individual citizens and emphasize the dignity, rights and obligations of individuals. In contrast, China, due to the combination of traditional moral values, uncertainty of death criteria, and economic interests, thus focuses more on the family and society to promote individual organ donation and transplantation(28).

\section{Ethical dilemmas of organ transplantation in China}

\subsection{Ethical dilemmas of organ donation}

More and more citizens are participating in organ donation initiatives, but the number of organs donated is limited and far from enough to fill the huge gap in organ demand. For those patients who are waiting for organs, their donated organs can only meet the transplant needs of a small percentage of patients. Solving the shortage of organ sources is an urgent issue for the development of organ transplantation in China(29).

Since ancient times, people have been deeply influenced by the traditional ethical concept. Whether in life or after death, great attention is paid to the integrity of the body. This traditional moral ideology makes it difficult for cadaveric organ donation to gain widespread acceptance. For many people, donating a corpse or organs after death destroys the integrity of the body, is an unfilial act, and is psychologically unacceptable(29). Therefore, it has been argued that these traditional concepts in China are the biggest obstacle limiting the voluntary donation of cadaveric organs by citizens and that organ transplantation is contrary to traditional culture. However, in placing too much importance on the integrity of the corpse, people overlook that in our traditional culture, Confucius proposed the idea of benevolence and love, Mencius believed that people should be compassionate, and Buddhists emphasized that saving one life is better than creating a seven-level pagoda. These ideas are the strong support for organ donation.

Compared to voluntary organ donation in China, many Western countries such as France, Spain, Finland and Austria have increased the number of cadaveric organ donations by implementing "presumed consent" (25). A "presumed consent" system could also be implemented in China. As a potential organ donor, every citizen can make the decision to refuse post-mortem organ donation at any time. In short, such a system is a system of presumed consent that can be refused. From a utilitarian point of view, this system is ethical for the following reasons: for one, based on the risk-benefit ratio, for cadaveric organ donors, they bear little risk. For society, organ recipients and their families, the benefits far outweigh the risks. Second, under such a system, citizens can be altruistic as organ donors and self-serving as organ recipients; if they are both, then they are self-serving while being altruistic. Third, the implementation of a presumed consent system prompts most available cadaveric organs to work again to extend the lives of more transplant patients. This is the best use of cadaveric organs and facilitates the construction of a national transplant organ bank. Its implementation can largely moderate the imbalance between organ supply and demand.

However, this system divides citizens into two types of people, those who explicitly refuse or consent to organ donation after death, and those who do not explicitly refuse or consent to donate during their lifetime but are presumed by law to consent to donate their organs after their death. For the former, a citizen's decision to donate organs is based on the person's informed consent. This is essentially an adherence to the principle of respect for autonomy. However, for the latter, 
the informed consent of this group of people is clearly inadequate or even lacking due to factors such as age restrictions, low knowledge and culture, poor channels of information sources, and low popularity of relevant policies. For example, due to their young age and limited knowledge, children know little about the presumed consent system and organ donation, and the informed consent they express is limited. Because of unexpected events such as car accidents, earthquakes, and fires, it is obvious that presumed consent for organ donation after death is against the will of the individual for those citizens who have decided to refuse to donate but are too late to express it and die in an accident. Therefore, it is unethical to respect the autonomous decision of one group of people while ignoring the autonomy of another group of people based on humanitarianism.

Another ethical issue involved in cadaveric organ donation is the establishment and legalization of brain death criteria. To date, more than 80 countries in the world have established brain death criteria, including Japan, the United Kingdom, the United States, Germany, Spain and other countries(30). However, the established criteria and regulations for defining brain death are not uniform. The so-called brain death is simply understood as a state of death in which a person is in a state of loss of voluntary breathing, no vital signs, and irreversible loss of life-sustaining brain functions. Whether his heart is beating or not, the patient is dead. Brain death means the real death of a person, and it is more scientific than heart death. Therefore, some scholars have proposed that brain death should be legalized in China. The judgment standard of death directly affects the quality of the donor organ and the transplantation effect of the recipient. For organ transplantation, a high quality and active organ is the key to the success of the transplantation. Modern medicine has shown that the organs of brain-dead people are the best organ transplant donors. Even though the brain is dead, the beating of its heart is still able to provide blood to the body's organs. Organs are removed when there is a blood supply and do not lose their vitality due to hypoxia and ischemia. The better quality and vitality of the removed organ will enable it to function better and improve the success rate of the transplantation. It can be said that brain death legislation has largely solved the problem of insufficient organ donors and wasted cadaveric organ resources, and promoted the development of organ transplantation.

However, traditionally, China has been using cardiac death, i.e., "respiration, heart and pulse have stopped and pupils are dilated" as the criterion for death. It is widely believed that the beating of the heart is a symbol of the existence of a person's life. Even if a person is medically judged to be brain dead, the beating of his or her heart means that the person is still alive. Thus, if a brain-dead person had explicitly stated that he or she would donate organs while alive, removing organs from a brain-dead person who is still alive would undoubtedly be "murder". The current legal provisions, moral culture and medical judgment are in conflict. The implementation of brain death standards requires a broad base of people, social ethics and morality, and ideological support. Obviously, this deep-rooted concept of heart death makes the national recognition and acceptance of brain death low.

For living organ donation, there are two main ethical issues from the perspective of the organ donor. One, whether the benefits borne by the donor outweigh the risks. For a living organ donor, removing an organ or part of an organ can satisfy altruism, gain emotional rewards, and perhaps even receive some compensation financially and policy-wise. However, the lack of an organ causes irreversible damage to the body and affects future survival and quality of life. It also has a huge psychological impact on the donor, which may lead to suicide. Even if the surgery is successful, he risks life-threatening or even death due to complications from the surgery. If the surgery fails, then it can lead to such a lose-lose situation: on the one hand, it damages the health of the donor and on the other hand, it accelerates the death of the recipient. Not only does the donor not achieve its initial purpose, but in turn it must suffer psychological burden and pain, or even become a recipient and receive the next donor's organ. This is clearly in conflict with the principle of respect for life and the principle of do no harm/benefit. Second, whether the donors are truly autonomous and voluntary. Some people believe that although their act of donating living 
organs made out of free and informed consent is autonomous and voluntary, it is inevitable that they will be subject to kinship pressure and moral abduction(31). Based on this, it is difficult for the donor to be truly autonomous and voluntary. However, it should not be overlooked that China is a family-oriented society and people's socialization is inevitably influenced by their families. It is impossible for a donor to completely exclude family and social influences when making a choice. Thus, a choice made without violence or coercion and considering the possible risks and benefits of organ transplantation is a valid informed consent, in line with the principle of respect for autonomy.

It goes without saying that the ethical issues and controversies regarding the implementation of the presumed consent system, the issue of brain death legislation, the autonomy and voluntariness of the donor, and other ethical issues that exist in relation to cadaveric organ donation and living organ donation hinder the expansion of transplantation sources in China.

\subsection{Ethical dilemmas of organ allocation}

Available information shows that there are currently about 300,000 patients with organ failure in need of organ transplantation in China on an annual basis. However, due to insufficient organ donations, only about 10,000 patients can undergo organ transplantation. It is difficult to balance the supply and demand of organs, and there are bound to be ethical issues in their allocation.

How to select and identify transplant recipients is a prominent ethical issue in allocation. Based on humanitarianism and utilitarianism, scholars believe that a comprehensive judgment should be made from various aspects such as medical factors, social factors, individual and social coping ability, and medical development needs.

The determination of the recipient of transplanted organs should first start from medical criteria. The medical criteria include the severity of the patient's condition, transplantation risk, immune compatibility, surgical success rate, and personal coping ability, where personal coping ability refers to the patient's psychological quality, lifestyle, and living environment to cope and cooperate with surgical treatment. Therefore, a comprehensive assessment of the patient is made through these components, and a more objective result is used to determine whether the patient needs to undergo transplantation. Organ transplantation is based on the need of the patient's condition, and this criterion is a more objective and fair principle for the patient.

The selection of transplant patients by social criteria is based on the social contribution and value of the transplant patient and the degree of social coping ability. Among them, social coping ability includes the patient's economic conditions, family environment, and significance to others. In other words, people with high social value and social coping ability have the priority for transplantation. Based on this, proponents argue that the act of determining transplant recipients by social criteria is fair. The social criteria are based on medical criteria, and the patients who can receive transplants are first classified by fair medical criteria. And this number of transplant patients is not a minority. Due to the scarcity of transplanted organs, then it is necessary to construct an evaluation system to further screen out a portion of priority transplant recipients. This evaluation system is composed of social criteria. The small number of transplant patients determined based on seemingly unfair social criteria maintains relative equity. This social criterion, which is based on social values and the ability of society to cope, essentially reflects the utilitarian idea of ensuring the best interests of most of the society. Similarly, medical development needs are clearly considered from a utilitarian perspective. For example, the choice to transplant organs to the young rather than the elderly.

However, once the social standard, the medical development needs standard, which embodies utilitarianism is implemented, the interests of most socially disadvantaged groups, such as farmers, the disabled, and the elderly, who have lower social value, lower economic capacity, and contribute less to medical development, will be difficult to be guaranteed. From the humanitarian point of view, human life is equal and priceless, and people at the bottom of society and disadvantaged groups are equally entitled to medical resources. To measure a person by social 
standards and future contributions is undoubtedly to quantify people into numerical values, to equate them with advantages and disadvantages, and to objectify the meaning of human existence. This is a great disrespect for life. To some extent, organ transplantation becomes a privilege for a few in society. This exacerbates the inequity in the distribution of transplanted organs.

Although the current system of organ allocation in China does not completely solve the problem of fairness in organ allocation in our country. But our efforts to move closer to fairness under the existing conditions reflect respecting the principle of justice.

\subsection{Ethical dilemmas of organ trading}

It is undeniable that the scarce organs donated through legal channels cannot meet the huge demand for organs. The serious imbalance between the supply and demand of organs has led to the underground trade in human organs, and the sale of organs at explicit prices has become more and more frequent. The sale of organs has contributed to the formation and development of a human organ economy, and the commodification of the body is becoming increasingly evident. Although organ trading cannot solve the problem of organ shortage for transplantation, it has moderated the shortage of organ supply to a certain extent. Therefore, the question of whether the trade in human organs is legalized has given rise to discussion.

From the perspective of utilitarianism and humanitarianism, many scholars believe that human organ trading should be allowed. They argue that, on the one hand, trading in organs can provide a source of organs for patients in urgent need of organ transplants, and on the other hand, the poor can improve the quality of survival for themselves and their families by selling expensive organs, which is conducive to narrowing the gap between the rich and the poor in society. Second, legalizing and publicizing the trade in human organs, through the dual regulation of the government and the legal system, can restrain and crack down on lawless elements and eliminate the black market of underground organ trade. Third, respecting citizens' autonomy over their own bodies is a manifestation of humanitarianism. It is moral for citizens to buy and sell organs freely(32).

With the exception of a very few countries, such as Iran, which allow human organ trading, the vast majority of countries in the world have banned the sale of human organs by way of legislation. Despite the laws explicitly outlawing the sale of human organs, the trade in organs is still repeatedly prohibited. There are many ethical issues hidden behind its commercialization.

First, the trade in human organs seriously degrades the dignity of human beings. The three reasons for allowing organ transplants essentially use the end to justify the means. Turning transplant organ donation, which is used to treat organ disease and extend the life of the patient in order to realize the value of life and health, into a commercial means of pursuing material gain. This devalues the human person and challenges the dignity and value of human life. Organs, as parts of the human body, carry the same dignity of the human person. They are not objects and cannot be assigned a market value. The sale of organs is the process of stripping organs from the body and "materializing" them into valuable commodities that can be selected and traded at will in the marketplace, cut up and priced at will in monetary transactions, and made into tools of profit for businessmen. This behavior ostensibly respects human self-determination, but in essence leads to a loss of control over the rights and autonomy of the human body. If left unchecked, the sale of organs may deteriorate into the sale of human bodies, where human life is equated with money. This commodification of organs is a great disservice to human dignity and devalues the value and meaning of life.

Second, the sale of human organs can result in the exploitation of vulnerable groups. Because of the scarcity of human organs, once it enters the market, the price of organs is likely to continue to rise. According to the rules of the market transaction of the highest bidder, the rich can easily buy the needed organs, and even multiple organs. This results in a small percentage of transplanted organs being concentrated in a few people in society. For the poor, who have low affordability, it is difficult for them to pay for the transplant surgery, let 
alone purchase the high-priced organs, so much so that they choose to forgo the treatment. They may even be forced to sell their organs because they are in financial difficulties. This polarized organ market is a denial of the right to live and the right to life and health of the disadvantaged. It further widens the gap between the rich and the poor in the buying and selling transactions and exacerbates social inequity.

Finally, the sale of human organs breeds more illegal and criminal behavior. The huge profits from the sale of human organs induce black agents, lawless elements and social crime syndicates to use deception, inducement and even violence to remove the organs of others, or to force others to sell their organs. This huge black profit chain has triggered various criminal acts, such as intentional homicide and intentional injury. In recent years, reports of illegal trade in human organs have been in the press. It not only endangers people's physical and mental health, but also destroys social stability and harmony.

In addition, some people consider the act of a donor receiving financial or other forms of compensation after donating organs as a kind of paid sale, equating it to organ trading. This view confuses reasonable compensation with organ trading. There is a fundamental difference in the nature and purpose of the two. The former is a fair reward for the altruistic behavior of the donor and is motivated by recognition, encouragement, and promotion of more gratuitous donations, while the latter is a commercial act of treating organs as a commodity for the purpose of profiteering.

In summary, the trade in human organs is not ethically and morally defensible. There is no denying that the trade in human organs has its place and value. However, once we allow the legalization of human organ trade may create a moral slippery slope, making it slide into practices that society and the state should rightly prohibit, leading to a variety of social, ethical, and legal problems that will follow and seriously plague the development of people and society. It leads to a series of serious consequences for society and mankind, which are disasters that are difficult to eliminate.

\section{Discussion and conclusion}

In most cases, organ transplantation forces us to make not a medical-technical decision, but an ethical and moral one. Thus, ethical principles need to be followed when organ transplantation is performed in our country. Organ transplants that are difficult to perform in an ethical dilemma need to find strong support for them in ethics. T. Beauchamp and J. Childress proposed four basic principles of bioethics, namely the principle of do no harm, the principle of benefit, the principle of autonomy, and the principle of justice(33). As an issue area of concern in bioethics, organ transplantation in China, based on the four basic principles of bioethics, should follow the principles of respect for life, do no harm/benefit, respect for autonomy, and justice to make it ethically and morally legitimate.

\subsection{Principle of Respect for Life}

As we all know, the right to life is the most fundamental right of natural persons. Respect for life is the starting point of all social life and practical activities of human beings. Life is the benchmark of social morality and the basis of all human values. When life disappears, the values that are born with it also disappear. The theory of the sanctity of life holds that human life is supreme, sacred and inviolable. Life is priceless, and the principle of respect for life is the first law of action in health care activities. Therefore, the principle of respect for life is the primary principle that must be observed in organ transplantation.

The dignity of the human person is reflected in the ability to act in accordance with moral principles. Obviously, this kind of organ trading, which treats human organs as objects and puts a price on the market for others to choose and trade, has reduced life to a means and a tool, and is a trampling on human dignity.

As a life-saving treatment mode, organ transplantation is aimed at saving patients' lives and restoring their health. In the process of organ transplantation, the principle of respect for life is the highest principle. When other ethical principles conflict with the principle of respect for life, we should put respect for life first. Therefore, in or- 
gan transplantation, the lives of both the donor and the recipient are equally respected.

To deny the principle of respect for life is a callous disregard for the meaning of human existence. If a society does not respect life, but speaks highly of other ethical principles, then the moral system established by that society will only be a castle in the air.

\subsection{Principle of do no harm/benefit}

As the name implies, the do no harm/benefit principle means that in organ transplantation, on the one hand, harm to the donor and the recipient should be avoided or minimized as much as possible, so that harm is minimized. On the other hand, appropriate measures should be taken to benefit both parties and to maximize the benefits to both parties. Moreover, organ transplantation must be an operation where the benefits to both parties outweigh the risks(34). There is no doubt that organ transplantation not only costs a lot of money, but also entails risks to the life and health of the donor and the recipient.

Organ transplantation starts with the purpose of treating organ diseases. For the recipients, organ transplantation gives them the chance and hope of survival and restores their physical health for them. For the donors, they gain psychological satisfaction and happiness, achieving altruism and self-interest. However, during the organ transplantation procedure, it is inevitable that they will be harmed to some extent, even causing irreversible health damage. Both donors and recipients need to face surgical risks as well as post-operative risks. For living organ donors, their safety can hardly be absolutely guaranteed.

Unlike other medical procedures, organ transplantation is related to both the life safety and health of the donor and the recipient. Therefore, before transplantation, a risk assessment of the procedure should be performed to exclude factors that may endanger both the donor and the recipient. Organ transplantation should be performed only when the benefits for both the donor and the recipient outweigh the risks. In other words, organ transplantation should be performed on the premise that the quality of survival and quality of life can be significantly improved after transplantation(35).

\subsection{Principle of respect for autonomy}

In medical practice, it is crucial to respect the autonomy of the patient. In organ transplantation, the autonomy of both the donor and the recipient must be guaranteed.

The theoretical basis of the principle of respect for autonomy comes from Kant's idea of "respect for the human being". According to Kant, human reason makes human beings moral subjects, and human beings are always to be treated as ends and not only as means. Thus, respect for the human being should respect his moral subjectivity. Among them, self-determination is a direct way to highlight the moral subjectivity of human beings. Self-determination is the determination of one's own state or behavior without external pressure or moral abduction(36).

In organ transplantation, the principle of respect for autonomy requires respect for the self-determination of both the donor and the recipient regarding the handling of acts involving self-interest. In fact, this principle is largely expressed through true and valid informed consent, a choice made voluntarily and without external pressure or coercion.

There is no doubt that organ transplant donors, recipients or their guardians must be fully capable of acting autonomously, and there is no monetary transaction or moral abduction between the parties. Organ transplantation is performed with informed consent, which is respectful of the autonomy of both parties.

This does not mean, however, that physicians must act in accordance with the wishes of the donor and recipient if they give valid consent. Rather, the principle of do no harm/benefit should be combined with respect for autonomy to safeguard the interests of both parties while safeguarding the right to information and autonomy of the donor-recipient. Whether one chooses to donate an organ or receive an organ transplant, one should be fully aware of the possible risks and benefits of transplantation in order to 
better achieve self-determination and respect the autonomy of both parties.

\subsection{Principle of justice}

The basic requirement of justice is to respect the basic rights and dignity of every person equally. When we resort to equal justice in the medical field, it inevitably involves the problem of inequitable distribution of scarce medical resources. However, in fact, the fairness of organ allocation is greatly challenged. On the one hand, due to the current severe shortage of transplantable organ resources in China, the demand for organs far exceeds the supply. On the other hand, the cost of transplantation, which can reach hundreds of thousands of dollars, puts tremendous financial pressure on patients, who can hardly afford the high cost of organ transplantation. Many patients must give up transplanting their organs and wait helplessly for death. In the process of organ allocation, the lower social strata and disadvantaged groups with low financial capacity are invariably sacrificed and removed from the waiting list.

In the ethical perspective, life is equal. Although society cannot achieve absolute justice and equality, every effort should be made to give every patient the same chance to be saved and enjoy a fair distribution of medical resources. Following the principle of justice and distributing limited organ resources in a reasonable and fair manner is not only conducive to the advancement of organ transplantation, but also promotes social equity.

In general, organ transplantation in China should follow the principle of respect for life, the principle of no harm/benefit, the principle of respect for autonomy, and the principle of justice. However, we can find that due to the complexity of the real situation, there are various ethical issues that need to be solved in the current development of organ transplantation in China.

Funding: This work was supported by the Humanities and Social Science Fund of Ministry of Education of China (Grant Number 19YJCZH235; PI: Zheng ZANG) and the Major Projects of China's Ministry of Education's Key Research Center for Humanities and Social Sciences (Grant Number 17JJD720007).

Informed consent was obtained from all subjects involved in the study. According to national law, formal approval of this study is not mandatory. The authors declare no conflict of interest.

\section{References}

1. Barry JM, Murray JE. The First Human Renal Transplants. Journal of Urology 2006; 176(3): 888-890.

2. Dew MA, Jacobs CL, Jowsey SG, et al. Guidelines for the Psychosocial Evaluation of Living Unrelated Kidney Donors in the United States. American Journal of Transplantation 2010; 7(5): 1047-1054.

3. Trotter JF, Talamantes M, McClure M, et al. Right hepatic lobe donation for living donor liver transplantation: Impact on donor quality of life. Liver Transplantation 2001.

4. Svenaeus F. The Body as Gift, Resource or Commodity? Heidegger and the Ethics of Organ Transplantation. Journal of Bioethical Inquiry 2010; 7(2): 163-172.

5. Morais M, Da Silva RC MA, Duca WJ, et al. Families Who Previously Refused Organ Donation Would Agree to Donate in a New Situation: A Cross-sectional Study. Transplantation Proceedings 2012; 44(8): 2268-2271.

6. Pacheco Z, Alonzo E, Venegas I, et al. Presence in the Media of the Topic "Donation and Transplantation of Organs and Tissues" During the 2005 to 2007 Period in Venezuela as a Strategy to Improve Its Perception in Venezuelan Society. Transplantation Proceedings 2009; 41(8): 3462-3465.

7. Mosimann F. The Use of Executed Prisoners as a Source of Organ Transplants in China Must Stop. American Journal of Transplantation 2011; 11(6): 1342-1342.

8. Wilkinson D, Savulescu J. Should we allow organ donation euthanasia? Alternatives for maximizing the number and quality of organs for transplantation. Bioethics 2012; 26(1): 32-48.

9. Shu K H, et al. Outcome of Kidney Transplantation Using Organs from Executed Prisoners: Is It Justified Beyond the Ethical Issue? Journal of the Chinese Medical Association 2007; 70(5): 193-199.

10. Campobasso CP, Quaranta R, Dell'Erba A. Living Donor Kidney Transplant: Medicolegal and Insurance Aspects. Transplant Proc 2005; 37(6): 2439-2444. 
11. Sten JA. Rethinking the national organ transplant program: when push comes to shove. Journal of Contemporary Health Law \& Policy 1994; 11(1): 197-219.

12. Wright L. Ethical controversies in public solicitations for organs. Transplant Rev 2008, 22(3): 184-186.

13. Larijani B, Zahedi F, Ghafouri-Fard S. Rewarded gift for living renal donors. Transplantation Proceedings 2004; 36(9): 2539-2542.

14. Wilkinson, TM. Opt-out organ procurement and tacit consent. Journal of Medical Ethics 2012; 38(2): 74-75.

15. Norrie KM. Human Tissue Transplants: Legal Liability in Different Jurisdictions. The International and Comparative Law Quarterly 1985; 34(3): 442-469.

16. Montgomery RA. Living donor exchange programs: theory and practice. Br Med Bull 2011; 98(1): 21-30.

17. Aydin E. Regulations and Organ Transplantation in Turkey. European Journal of Health Law 2000; 7(3): 327-332.

18. Bagheri A. Organ Transplantation Laws in Asian Countries: A Comparative Study. Transplantation Proceedings 2005; 37(10): 4159-4162.

19. Price D, Akveld H. Living Donor Organ Transplantation in Europe: Re-evaluating its Role. European Journal of Health Law 1998; 5(1): 19-44.

20. Iyer T. Kidneys for transplant — "Opting out" law in Singapore. Forensic Science International 1987; 35(2-3): 131-140.

21. Hartogh GD. The role of the relatives in opt-in systems of postmortal organ procurement. Medicine, Health Care \& Philosophy 2012; 15(2): 195-205.

22. Kishore RR. Human Organs, Scarcities, and Sale: Morality Revisited. Journal of Medical Ethics 2005; 31(6): 362-365.

23. Ossareh S, Asl M B, Al-Zubairi S, et al. Attitude of Iranian Nephrologists Toward Living Unrelated Kidney Donation. Transplantation Proceedings 2007; 39(4): 819-821.

24. Cohen IG. Can the Government Ban Organ Sale? Recent Court Challenges and the Future of US Law on Selling Human Organs and Other Tissue. American Journal of Transplantation 2012; 12(8): 1983-1987.

25. Abadie A, Gay S. The impact of presumed consent legislation on cadaveric organ donation: A cross-country study. Journal of Health Economics 2006; 25(4): 599-620.

26. Wang M, Wang X. Organ Donation by Capital Prisoners in China: Reflections in Confucian Ethics. Journal of Medicine \& Philosophy 2010; 2: 197.

27. Delmonico F L, Capron A M, Danovitch G M, et al. Organ transplantation in China—not yet a new era. Lancet 2014; 384(9945): 741-741.

28. Ding ZY, Zhang Q, Wu JW, et al. A Comparison of Brain Death Criteria between China and the United States. Chinese Medical Journal 2015; 128(021): 2896-2901.

29. Wang M, Wang X. Organ Donation by Capital Prisoners in China: Reflections in Confucian Ethics. Journal of Medicine \& Philosophy 2010; 2: 197.

30. Iltis, A S. Organ Donation, Brain Death and the Family: Valid Informed Consent. J Law Med Ethics 2015; 43(2): 369 382.

31. Morgan D. Legal and Ethical Aspects of Organ Transplantation. Journal of Medical Ethics 2002; 28(5).

32. Delmonico F L, Arnold R, Scheper-Hughes N, et al. Ethical incentives — not payment - for organ donation. The New England Journal of Medicine 2002; 346(17): 2002-2005.

33. Beauchamp TL, Childress JE. Principles of Biomedical Ethics. 8th ed. New York: Oxford University Press; $2019: 217-$ 256.

34. Kolber AJ. A Matter of Priority: Transplanting Organs Preferentially to Registered Donors[J]. Rutgers Law Review 2003; 55(3): 671

35. Kallich JD, Merz JF. The transplant imperative: protecting living donors from the pressure to donate. Journal of Corporation Law 1994; 20:139.

36. Cate FH. Human Organ Transplantation: The Role of Law. Journal of Corporation Law 1994; 69: 69-90.

Received: April 15, 2021

Accepted: May 20, 2021 